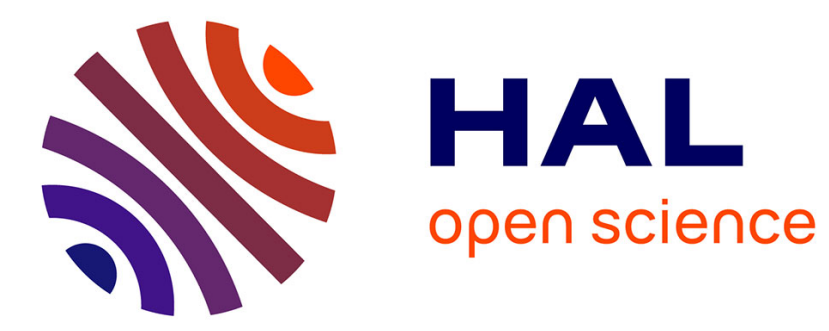

\title{
Hybrid Solar - a Review on Photovoltaic and Thermal Power Integration
}

\author{
T.T Chow, G.N. Tiwari, Christophe Menezo
}

\section{To cite this version:}

T.T Chow, G.N. Tiwari, Christophe Menezo. Hybrid Solar - a Review on Photovoltaic and Thermal Power Integration. International Journal of Photoenergy, 2012, 2012, pp.307287. 10.1155/2012/307287. hal-00778007

\section{HAL Id: hal-00778007 https://hal.science/hal-00778007}

Submitted on 4 Mar 2014

HAL is a multi-disciplinary open access archive for the deposit and dissemination of scientific research documents, whether they are published or not. The documents may come from teaching and research institutions in France or abroad, or from public or private research centers.
L'archive ouverte pluridisciplinaire HAL, est destinée au dépôt et à la diffusion de documents scientifiques de niveau recherche, publiés ou non, émanant des établissements d'enseignement et de recherche français ou étrangers, des laboratoires publics ou privés. 


\title{
Review Article
}

\section{Hybrid Solar: A Review on Photovoltaic and Thermal Power Integration}

\author{
T. T. Chow, ${ }^{1}$ G. N. Tiwari, ${ }^{2}$ and C. Menezo ${ }^{3}$ \\ ${ }^{1}$ Building Energy and Environmental Technology Research Unit, Division of Building Science and Technology, \\ City University of Hong Kong, Tat Chee Avenue, Hong Kong \\ ${ }^{2}$ Centre for Energy Studies, Indian Institute of Technology Delhi, Hauz Khas, New Delhi 1100 16, India \\ ${ }^{3}$ CETHIL UMR 5008, Domaine Scientifique de La Doua, INSA de Lyon, 9 Rue de la Physique, \\ 69621 Villeurbanne Cedex, France
}

Correspondence should be addressed to T. T. Chow, bsttchow@cityu.edu.hk

Received 23 August 2012; Accepted 9 November 2012

Academic Editor: Mark van Der Auweraer

Copyright $\odot 2012$ T. T. Chow et al. This is an open access article distributed under the Creative Commons Attribution License, which permits unrestricted use, distribution, and reproduction in any medium, provided the original work is properly cited.

\begin{abstract}
The market of solar thermal and photovoltaic electricity generation is growing rapidly. New ideas on hybrid solar technology evolve for a wide range of applications, such as in buildings, processing plants, and agriculture. In the building sector in particular, the limited building space for the accommodation of solar devices has driven a demand on the use of hybrid solar technology for the multigeneration of active power and/or passive solar devices. The importance is escalating with the worldwide trend on the development of low-carbon/zero-energy buildings. Hybrid photovoltaic/thermal (PVT) collector systems had been studied theoretically, numerically, and experimentally in depth in the past decades. Together with alternative means, a range of innovative products and systems has been put forward. The final success of the integrative technologies relies on the coexistence of robust product design/construction and reliable system operation/maintenance in the long run to satisfy the user needs. This paper gives a broad review on the published academic works, with an emphasis placed on the research and development activities in the last decade.
\end{abstract}

\section{Introduction}

In the past 3-4 decades, the market of solar thermal and photovoltaic (PV) electricity generation has been growing rapidly. So were the technological developments in hybrid solar photovoltaic/thermal (PVT) collectors and the associated systems. Generally speaking, a PVT system integrates photovoltaic and solar thermal systems for the co-generation of electrical and thermal power from solar energy. A range of methods are available such as the choices of monocrystalline/polycrystalline/amorphous silicon (c-Si/pc-Si/a-Si) or thin-film solar cells, air/liquid/evaporative collectors, flatplate/concentrator types, glazed/unglazed designs, natu$\mathrm{ral} /$ forced fluid flow, and stand-alone/building-integrated features. Accordingly, the systems are ranging from PVT air and/or water heating system to hot-water supply through PV-integrated heat pump/pipe or combined heating and cooling and to actively cooled PV concentrator through the use of lens/reflectors. Engineering considerations can be on the selection of heat removal fluid, the collector type, the balance of system, the thermal to electrical yield ratio, the solar fraction, and so on. These all have determining effects on the system operating mode, working temperature, and energy performance.

Theoretical and experimental studies of PVT were documented as early as in mid 1970s [1-3]. Despite the fact that the technical validity was early concluded, only in recent years that it has gained wide attention. The amount of publications grows rapidly. The following gives an overview of the development of the technology, placing emphasis on the research and development activities in the last decade. Readers may refer to Chow [4] for a better understanding of the early developments.

\section{PVT Developments in the Twentieth Century}

2.1. Early Works on Collector Design. The early research works were mainly on flat-plate collectors $[5,6]$. Garg and 
his coworkers carried out mathematical and experimental studies on PVT systems [7-9]. Sopian et al. developed steadystate models, for comparing the performance of single- and doublepass PVT/a collectors [10, 11]. Through transient analysis, Prakash [12] pointed out that the air collector (PVT/a) design is lower in thermal efficiency than the water collector $(\mathrm{PVT} / \mathrm{w})$, because of the inferior heat transfer between the thermal absorber and the airflow stream. Bergene and Løvvik [13] derived a detailed physical model of a flat-plate PVT/w collector, through which the total efficiency was evaluated.

de Vries [14] investigated the performance of several PVT collector designs. The single-glazed design was found better than the unglazed (of which the thermal efficiency is unfavorable) or the double-glazed design (of which the electrical efficiency is unfavorable). Nevertheless, exergy analysis performed by Fujisawa and Tani [15] indicated that the exergy output density of the unglazed design is slightly higher than the single-glazed option, taking the fact that the thermal energy contains more unavailable energy. For low temperature water heating applications like for swimming pool-water heating, the unglazed PVT/w system is recommended. In cold winter days, antifreeze liquid can be used but then the summer performance will be affected [16].

Rockendorf et al. [17] compared the performance of a thermoelectric collector (first generating heat and subsequently electricity) and a PVT/w collector (in sheet-and-tube design); the electrical output of the PVT/w collector was found significantly higher than the thermoelectric collector.

In the above mathematical and experimental studies, the reported thermal efficiency of practical PVT/liquid systems is generally in the range of 45 to $70 \%$ for unglazed to glazed collector designs. For flat-plate PVT/a systems, the optimal thermal efficiency can be up to $55 \%$.

2.2. Developments towards Complex Systems. In the 1990s, the initiative of PVT research was apparently a response to the global environmental deterioration and the growing interest in building-integrated photovoltaic (BiPV) designs. Comparing with the separated PV systems, the building integration of PV modules improves the overall performance and durability of the building facade. Nevertheless, building integration may bring the cell temperatures up to $20^{\circ} \mathrm{C}$ above the normal working temperature [18]. Other than the benefits of cooling, PVT collectors provide aesthetical uniformity than the side-by-side arrays of PV and solar thermal collectors. Alternative cooling schemes of the BiPV systems were examined [19-21]. Hollick [22] assessed the improvement in the system energy efficiency when solar cells were added onto the solar thermal metallic cladding panels on vertical facades.

Continued successfulness on concentrator-type (c-PVT) systems began to take shape. Akbarzadeh and Wadowski [23] studied a heat-pipe-based coolant design which is a linear, trough-like system. Luque et al. [24] successfully developed a concentrating array using reflecting optics and one-axis tracking. By that time, facing the conflicting roles of water heating and PV cooling, the design temperature of water that leaves a PVT/w collector is not high. Combining PVT and solar-assisted heat pump (SAHP) technology was then seen as a good alternative. Ito et al. [25] constructed a PVT-SAHP system with pc-Si aluminum roll-bond solar panels.

Generally speaking, in the 20th century the PVT research works had been mostly focused on improving the costperformance ratio as compared to the solar thermal and PV systems installed side by side. For real-building projects the PVT/a systems were more readily adopted in Europe and North America, though the higher efficiency of the PVT/w system has been confirmed by that time. Solar houses with PVT/w provision were once sold in Japan in late 1990s. Unfortunately such innovative housing was in lack of demand in the commercial market [26]. A summary of the PVT technology in the period, including the marketing potentials, was reported by the Swiss Federal Office [27] and the International Energy Agency (IEA) [28].

\section{Recent Developments in Flat-Plate PVT}

\subsection{PVT Air Collector Systems}

3.1.1. Collector Design and Performance. The PVT air collectors, either glazed or unglazed, provide simple and economical solution to PV cooling. The air can be heated to different temperature levels through forced or natural flow. Forced circulation is more effective than natural circulation owing to better thermal convective and conductive behavior, but the fan power consumption reduces the net electricity output. Their use is mostly to meet the demands on industrial hot air, indoor space heating, and/or agricultural dehydration.

Hegazy investigated the thermal, electrical, hydrodynamic, and overall performance of four types of flat-plate PVT/a collectors [29]. These included channel above PV as Mode 1, channel below PV as Mode 2, PV between singlepass channels as Mode 3, and finally the double-pass design as Mode 4 . The numerical analysis showed that while Mode 1 has the lowest performance, the other three have comparable energy outputs. On the whole, Mode 3 requires the least fan power.

Tripanagnostopoulos et al. carried out outdoors tests on different PVT/a and PVT/w collector configurations in Patra, Greece [30]. It was suggested to place the collectors in parallel rows and keeping a distance between adjacent rows to avoid shading. Diffuse reflectors then were placed between the adjacent rows to enlarge the received radiation at collector surfaces. Their experimental tests at noon hour gave a range of thermal efficiency from $38 \%$ to $75 \%$ for PVT/a collectors and $55 \%$ to $80 \%$ for PVT/w designs, depending on whether the reflectors were in place. The research team [31] further studied numerically the effect of adding suspended metal sheet at the middle of the air channel and the finned arrangements at the opposite wall of the air channel. It was found that such low cost improvements are more relevant to small collector length and can be readily applied to BiPVT/a installations. They [32] also introduced a PVT/bifluid collector incorporated with improvements identified in their previous work. 
Tiwari et al. explored the overall efficiency performance and optimal designs of an unglazed PVT/a collector [33]. Energy matrices were derived considering the embodied energy at different processing stages in India [34]. Raman and Tiwari [35] then studied the annual thermal and exergy efficiencies of their proposed PVT/a collector for five different climate zones. The exergy efficiency was found unfavorable under strong solar radiation. Also the doublepass design shows better performance than the single-pass option; this echoes the findings of Sopian et al. [10] and Hegazy [29]. Furthermore, the life cycle analysis showed that the energy payback time (EPBT) in India is about 2 years. Also evaluated were the effect of fill factor [36] and the integrated performance with an earth air heat exchanger system [37]. Further, Dubey et al. [38] compared different configurations of glass-to-glass and glass-to-tedlar PV modules in Delhi. Experiments found that the glass-toglass module is able to achieve higher supply air temperature and electrical efficiency. Their study extended to derive the analytical expressions for multiple PVT/a collectors connected in series, including the testing procedures $[39,40]$.

Assoa et al. in France introduced a PVT/bi-fluid collector that integrates preheating and domestic hot-water production [41]. The design includes alternate positioning of the solar thermal collector section and the PV section. The higher fluid temperature output allows the flexibility such as coupling with solar cooling devices during summer and facilitates a direct domestic hot-water system without adding auxiliary heating device. Parametric studies showed that the thermal efficiency could reach $80 \%$ under favorable collector length and mass flow rate conditions.

Sukamongkol et al. [42] studied the dynamic performance of a condenser desiccant for air conditioning energy reduction with the use of double-pass PVT/a collector. The thermal energy generated by the system was able to produce warm dry air as high as $53^{\circ} \mathrm{C}$ and $23 \%$ relative humidity. Electricity of about $6 \%$ of the daily total solar radiation can be obtained. Moreover, together with the heat recovery from the condenser to regenerate the desiccant for dehumidification, around $18 \%$ of the air conditioning energy can be saved.

Ali et al. [43] investigated the characteristics of convective heat transfer and fluid flow inside a PVT/a channel with the provision of a single row of oblique plates array. These plates arrays were positioned obliquely to the flow direction with variable oblique angles and with separations that avoid the partial shading of solar cells. The study was initiated taking the fact that the entrance region of a heated fluid flow channel is characterized by differentiating thermal and hydrodynamics boundary layers; the convective heattransfer coefficient is then substantially larger than that at downstream locations. Thus, using oblique (interrupted) plates in a duct, or a channel, to prevent fully developed flow formation has the advantage of obtaining enhanced heattransfer characteristics.

Kumar and Rosen [44] investigated the effect of adding vertical fins to the lower air channel of a double-pass PVT/a collector. The extended fin area was found able to reduce the cell temperature significantly.
3.1.2. Building-Integrated Options (BiPVT/a). In conventional BiPV systems, an air gap is often provided at the rear of the PV arrays for the air cooling of modules by natural convection. The heat recovery from the air stream for a meaningful use constitutes a BiPVT/a system. From a holistic viewpoint, Bazilian and Prasad [45] summarized its potential applications. The multifunctional façade or roof was ideal for PVT integration that produces heat, light, and electricity simultaneously, in addition to the building shelter functionality.

(1) Works in Europe. In UK, the Brockstill Environment Centre in Leicester opened in 2001 was equipped with a roofmounted PVT/a system [46]. To assess the performance of various operational and control modes, a combined simulation approach was adopted with the use of two popular thermal simulation tools: ESP-r and TRNSYS. Monitored actual energy use data of the building shows very positive results.

Mei et al. [47] studied the dynamic performance of a BiPVT/a collector system constructed in the $90 \mathrm{~s}$ at the Mataro Library in Spain. Their TRNSYS model was validated against experimental data from a $\mathrm{pc}-\mathrm{Si} \mathrm{PV}$ facade. The heating and cooling loads for various European buildings with and without such a ventilated facade were then evaluated. The simulation results showed that more winter heating energy can be saved for the use of the preheated ventilation in a building located in Barcelona, but less is for Stuttgart in Germany and Loughborough in UK. The higher latitude locations therefore need a higher percentage of solar air collectors in the combined system. Further, Infield et al. [48] explored different approaches to estimate the thermal performance of BiPVT/a facades, including a design methodology based on an extension of the familiar heat loss and radiation gain factors.

The main difficulty in analyzing BiPVT/a performance lies in the prediction of its thermal behavior. When the temperature profile and the sun shading situation are known, the electrical performance can be readily determined. This is not the case for thermal computation. The estimation of the convective heat-transfer coefficients, for example, is far from direct. The actual processes may involve a mix of forced and natural convection, laminar and turbulent flow, and, simultaneously, the developing flow at the air entrance. The external wind load on the panels further complicates the situation. For a semitransparent facade, thermal energy enters and transmits through the air cavity both directly (for glazing transmission) and indirectly (through convection and radiation exchange). The heat transfer to the ventilating stream is probably most complex, particularly for buoyant flow.

Sandberg and Moshfegh derived analytical expressions for the coolant flow rate, velocity, and temperature rise along the length of the vertical channel behind the PV panels [49]. Their experimental results were well matching the theoretical predictions for constrained flow, but were less accurate for ducts with opened ends. For the latter, Mittelman et al. developed a generalized correlation for the average channel Nusselt number for the combined convective-radiative 
cooling [50]. Their solution of the governing equations and boundary conditions was computed through CFD analysis. Gan also studied the effect of channel size on the PV performance through CFD analysis [51]. To reduce possible overheating or hot spot formation, the required minimum air gaps were determined. Experimental works on a PVT façade were undertaken by Zogou and Stapountzis [52] for better understanding of the flow and turbulence with natural and forced convection modes. Supported by CFD modeling, the results show that the selection of flow rate and the heattransfer characteristics of the back sheet are critical.

(2) Works in North America. In Canada, Chen et al. [53, 54] introduced a BiPVT/a system to a near net-zero energy solar house in Eastman Quebec. The solar house, built in 2007, featured with ventilated concrete slabs (VCSs). A VCS is a type of forced-air thermoactive building systems in which the concrete slabs exchange thermal energy with the air passage through its internal hollow voids. The BiPVT system is designed to cover one continuous roof surface to enhance aesthetic appeal and water proofing. Outdoor air is drawn by a variable speed fan with supervisory control to achieve the desired supply temperature. On a sunny winter day, the typical air temperature rise was measured $30-35^{\circ} \mathrm{C}$. The typical thermal efficiency was at least $20 \%$ based on the gross roof area. Analysis of the monitored data showed that the VCS was able to accumulate thermal energy during a series of clear sunny days without overheating the slab surface or the living space.

Athienitis et al. [55] presents a design concept with transpired collector. This was applied to a full-scale office building demonstration project in Montreal. The experimental prototype was constructed with UTC (open-loop unglazed transpired collector) of which $70 \%$ surface area was covered with black-frame PV modules specially designed to enhance solar energy absorption and heat recovery. The system was compared side by side with a UTC of the same area under outdoor sunny conditions with low wind. This project was considered a near optimal application in an urban location in view of the highly favorable system design. While the thermal efficiency of the UTC system was found higher than the BiPVT/a combined thermal plus electrical efficiency, the equivalent thermal efficiency of the BiPVT/a system (assuming that electricity can be converted to four times as much heat) can be $7-17 \%$ higher.

Pantic et al. [56] compared 3 different open-loop systems via mathematical models. These include Configuration 1: unglazed BiPVT roof, Configuration 2: unglazed BiPVT roof connected to a glazed solar air collector, and Configuration 3: glazed BiPVT. It was pointed out that air flow in the BiPVT cavity should be selected as a function of desired outlet temperatures and fan energy consumption. Cavity depths, air velocity in the air cavity, and wind speed were found having significant effect on the unglazed BiPVT system energy performance. Development of efficient fan control strategies has been suggested an important step. Configurations 2 and 3 may be utilized to significantly increase thermal efficiency and air outlet temperature. In contrast, Configuration 3 significantly reduces electricity production and may lead to excessive cell temperatures and is thus not recommended unless effective means for heat removal are in place. The unglazed BIPVT system linked to a short vertical solar air collector is suitable for a connection with a rock bed thermal storage.

(3) Works in Asia Pacific. For warm climate applications, the ventilated BiPV designs are found better than the PVT/a designs with heat recovery. Crawford et al. [57] compared the EPBT of a conventional c-Si BiPV system in Sydney with two BiPVT/a systems with c-Si and a-Si solar cells, respectively. They found that the EPBT of the above three installations are in the range of 12-16.5 years, 4-9 years, and 6-14 years, respectively. The two BiPVT/a options reduce the EPBT to nearly one-half.

Agrawal and Tiwari $[58,59]$ studied a BiPVT/a system on the rooftop of a building, under the cold climatic conditions of India. It is concluded that for a constant mass flow rate of air, the series connected collectors are more suitable for the building fitted with the BIPVT/a system as rooftop. For a constant velocity of air flow, the parallel combination is then the better choice. While the c-Si BiPVT/a systems have higher energy and exergy efficiencies, the a-Si BiPVT systems are the better options from the economic point of view.

Jie et al. [60] studied numerically the energy performance of a ventilated BiPV façade in Hong Kong. It was found that the free airflow gap affects little the electrical performance, but is able to reduce the heat transmission through the PV façade. Yang et al. [61] carried out a similar study based on the weather conditions of three cities in China: Hong Kong, Shanghai, and Beijing. It was found that on typical days the ratio of space cooling load reduction owing to the ventilated $\mathrm{PV}$ facade is $33-52 \%$.

Chow et al. [62] investigated the BiPVT/a options of a hotel building in Macau, with the PVT facade associated with a 24-hour air-conditioned room. The effectiveness of PV cooling by means of natural airflow was investigated with two options: free openings at all sides of the air gap as Case 1 and in Case 2 the enclosed air gap that behaves as a solar chimney for air preheating. These were also compared with the conventional BiPV without ventilation. The ESP$r$ simulation results showed an insignificant difference in electricity output from the three options. This was caused by a reverse down flow at the air gap at night, owing to the cooling effect of a 24-hour air-conditioned room located behind the PVT facade. It was concluded that both the climate condition and system operating mode affect significantly the PV productivity.

In China, Ji et al. [63] studied theoretically and experimentally the performance of a photovoltaic-Trombe wall, which was constructed at an outdoor environmental chamber. This south-facing façade in Hefei was composed of a PV glazing (with pc-Si cells) at the outside and an insulation wall at the inside with top and bottom vent openings. This leaves a natural flow air channel in between for space heating purpose. The results confirmed its dual benefits-improving the room thermal condition (with $5-7^{\circ} \mathrm{C}$ air temperature rise in winter) and generating electricity (with cell efficiency at $10.4 \%$ on average). 
(4) Works on Window Systems. In Sweden, a multifunction PVT hybrid solar window was proposed by Fieber et al. [64]. The solar window is composed of thermal absorbers on which PV cells are laminated. The absorbers are building integrated into the inside of a standard window, thus saving frames and glazing and also the construction cost. Reflectors are placed behind the absorbers for reducing the quantity of cells. Via computer simulation, the annual electrical output shows the important role of diffuse radiation, which accounts for about $40 \%$ of the total electricity generation. Compared to a flat PV module on vertical wall, this solar window produces about 35\% more electrical energy per unit cell area.

Vertical collectors and windows are more energy efficient at high-latitude locations, considering the sun path. Davidsson et al. [65] studied the performance of the above hybrid solar window in Lund, Sweden $\left(55.44^{\circ} \mathrm{N}\right)$. Also a full-scale system combining four of these solar windows was constructed in a single family home in Alvkarleo, Sweden $\left(60.57^{\circ} \mathrm{N}\right)$. The solar window system was equipped with a PV-driven DC pump. The projected solar altitude is high in summer, and accordingly a large portion of the solar beam falls directly onto the absorber with a minor contribution from the reflector. This is the ideal operating mode of the solar window, with the reflector partly opened and the window delivers heat, electricity, and light altogether. Effects of different control strategies for the position of the rotatable reflector were also studied, so was the performance comparison with roof collector [66].

A ventilated PV glazing consists of a PV outer glazing and a clear inner glazing. The different combinations of vent openings allow different modes of ventilating flow, which can be buoyant/induced or mechanical/driven. The space heating mode belongs to the BiPVT/a category. Besides the popularly used opaque c-Si solar cells on glass, the seethrough a-Si solar window can also be used. Chow et al. [67] analyzed its application in the office environment of Hong Kong. The surface transmissions were found dominated by the inner glass properties. The overall heat transfer however is affected by both the outer and inner glass properties. Experimental comparisons were made between the use of PV glazing and absorptive glazing [68]. The comparative study on single, double, and double-ventilated cases showed that the ventilated PV glazing is able to reduce the direct solar gain and glare effectively. The savings on airconditioning electricity consumption are $26 \%$ for the singleglazing case and $82 \%$ for the ventilated double-glazing case. Further, via a validated ESP-r simulation model [69], the natural-ventilated PV technology was found reducing the air-conditioning power consumption by $28 \%$, comparing with the conventional single absorptive glazing system. With daylight control, additional saving in artificial lighting can be enhanced [70].

\subsection{PVT Liquid Collector Systems}

\subsubsection{PVT/w Collectors}

(1) Collector Design and Applications. Zondag et al. compared the energy performance of different PVT/w collector design configurations $[71,72]$. The efficiency curves of nine collector configurations were obtained through computer analysis. At zero reduced temperature, the thermal efficiencies of the unglazed and single-glazed sheet-and-tube collectors were found $52 \%$ and $58 \%$, respectively, and that of the channel-above-PV design is $65 \%$. Also compared were the annual yields when these collectors were assumed to serve a DHW system. The channel-below-PV (transparent) configuration was found having the highest overall efficiency. Nevertheless, the more economical single-glazed sheet-andtube design was recommended for DHW production since its efficiency was found only $2 \%$ less. For low-temperature water heating, the unglazed PVT/w collector is recommended.

Sandnes and Rekstad developed a PVT/w collector with c-Si solar cells pasted on polymer thermal absorber [73]. Square-shape box-type absorber channels were filled with ceramic granulates. This improves heat transfer to flowing water. The opposite surface was in black color which allows it to serve as a solar thermal collector when turned up-sidedown. The analysis showed that the presence of solar cells reduces the heat absorption by about $10 \%$ of the incident radiation, and the glazing (if exists) reduces the optical efficiency by around 5\%. It was expected to serve well in lowtemperature water-heating system.

Chow introduced an explicit dynamic model for analyzing transient performance of single-glazed sheet-andtube collector [74]. Through the multinodal finite different scheme, the dynamic influences of intermittent solar irradiance and autocontrol device operation can be readily investigated. The appropriateness of the nodal scheme was evaluated through sensitivity tests. The study also reveals the importance of having good thermal contact between the water tubing and the thermal absorber, as well as between the absorber and the encapsulated solar cells.

Zakharchenko et al. also pointed out the importance of good thermal contact between solar cells and thermal absorber [75]. So the direct use of commercial PV module in PVT collectors is not recommended. They introduced a substrate material with $2 \mathrm{~mm}$ aluminum plate covered by $2 \mu \mathrm{m}$ insulating film, of which the thermal conductivity was only $15 \%$ less than that of aluminum. They also pointed out that the solar cell area should be smaller than the size of the absorber and should be at the portion of the collector where the coolant enters. As an echo to this last point, Dubey and Tiwari [76] examined the performance of a self-sustained single-glazed PVT/w collector system with a partial coverage of PV module (packing factor $=0.25$ ) in Delhi. The electricity generated from the PV module positioned at the water inlet end was used to drive a DC pump.

Kalogirou [77] developed a TRNSYS model of a pumpoperated domestic PVT/w system complete with water tank, power storage and conversion, and temperature differential control. Further, Kalogirou and Tripanagnostopoulos [78] examined domestic PVT/w applications working with either thermosyphon or pump circulation modes. Their simulation study covered 12 cases with pc-Si and a-Si PV modules, and in three cities: Athens in Greece, Nicosia in Cyprus, and Madison in USA. The results showed that the economical advantage is more obvious for Nicosia and Athens where the 
availability of solar radiation is higher. Similar conclusions can be reached when comparing comparable applications at an industrial scale [79]. Also in Cyprus, Erdil et al. [80] carried out experimental measurements on an open-loop PVT/w domestic water-preheating system. Water flowed by gravity into a channel-above-PV type collector. The CPBT was estimated around 1.7 years.

Vokas et al. [81] performed a theoretical analysis of PVT/w application in domestic heating and cooling systems in three cities that belong to different climate zones, namely, Athens, Heraklion, and Thessaloniki. The thermal efficiency was found around 9\% lower than the conventional solar thermal collector. Hence the interpolation of the PV laminate only affects slightly the thermal efficiency. The difference between the mentioned two systems in the percentage of domestic heating and cooling load coverage is only around $7 \%$.

The effect of reflectors on PVT/w collector equipped with c-Si solar cells was studied by Kostić et al. [82]. Both numerical computation and experimental measurements arrived at the same optimal angle positions of the bottom reflector. The results show the positive effect of reflectors made of aluminum sheet and, considering the additional cost of about $10 \%$ for the reflectors, there is an energy gain in the range of $20.5-35.7 \%$ in summer.

Saitoh et al. [83] carried out the experimental study of a single-glazed sheet-and-tube PVT collector using brine (propylene glycol) solution as the coolant. Field measurements at a low energy house in Hokkaido were also observed. With a solar fraction of $46.3 \%$, the system electrical efficiency was $8-9 \%$ and thermal efficiency $25-28 \%$. When compared with the conventional system, the payback periods were found 2.1 years for energy, 0.9 years for GHG emission, and 35.2 years for cash flow, respectively.

The use of optimized working fluid (like nanofluid) was proposed through a numerical study by Zhao et al. [84]. The system consists of a PV module using c-Si solar cell and a thermal unit based on the direct absorption collector (DAC) concept. First the working fluid of the thermal unit absorbs the solar infrared radiation. Then, the remaining visible light is transmitted and converted into electricity by the solar cell. The arrangement prevents the excessive heating of the solar cell. The system works for both nonconcentrated and concentrated solar radiation. The optical properties of the working fluid were optimized to maximize the transmittance and the absorptance of the thermal unit in the visible and infrared part of the spectrum, respectively.

Chow et al. compared the performance of glazed and unglazed sheet-and-tube thermosyphon PVT/w collector systems in Hong Kong through theoretical models as well as experimental tests [85]. The evaluation indicates that the glazed design is always suitable if either the thermal or the overall energy output is to be maximized, but the exergy analysis supports the use of unglazed design if the increase of PV cell efficiency, packing factor, ratio of water mass to collector area, and wind velocity are seen as the desirable factors. Similar experimental work was done by J. H. Kim and J. T. Kim in Korea [86]; the results show that the thermal efficiency of the glazed collector is $14 \%$ higher than the unglazed alternative, but the unglazed one had electrical efficiency $1.4 \%$ higher than the glazed design. Further for the unglazed option, they compared the performance of the conventional sheet-and-tube thermal absorber with the rectangular-box-channel design, which was made of aluminum. At zero reduced temperature, the thermal and electrical efficiencies were found $66 \%$ and $14 \%$, respectively, whereas those of the box-channel configuration were $70 \%$ and $15 \%$, respectively [87].

Dubey and Tiwari [88] analyzed the thermal energy, exergy, and electrical energy yield of PVT/w sheet-and-tube collectors in India. Based on a theoretical model, the number of collectors in use, their series/parallel connection patterns, and the weather conditions were examined. For enhancing economical/environmental benefits, the optimum hot-water withdrawal rate was evaluated [89]. Optimum PVT/w system configuration was also evaluated by Naewngerndee et al. [90] via CFD employing the finite element method.

Rosa-Clot et al. [91] suggested a PVT configuration with water flow in polycarbonate box above the PV panel. The water layer absorbs the infrared radiation leaving the visible part almost unaffected. Efficiencies were evaluated and in particular the effects of temperature and irradiance mismatching on PV outputs were discussed.

(2) Absorber Materials. In view of the limitations on the fin performance of a sheet-and-tube PVT/w collector [74], an aluminum-alloy box-channel PVT/w collector was developed through the collaborative efforts of the City University of Hong Kong and the University of Science and Technology of China. Several generations of the collector prototypes were produced and tested under the subtropical Hong Kong and temperate Hefei climatic conditions [9295]. The thermosyphon system was found working well in both locations. Dynamic simulations showed that better convective heat transfer between the coolant and the channel wall can be achieved by reducing the channel depth and increasing the number of channels per unit width [95]. Sensitivity tests in Hefei showed that the daily cell efficiency reaches $10.2 \%$, daily primary energy saving efficiency reaches $65 \%$ with a packing factor of 0.63 [96]. In Hong Kong, the CPBT was found to be 12 years which is comparable to the more bulky side-by-side arrangement and is much better than the 52 years for plain PV module operation [97].

Affolter et al. [98] pointed out that the typical solar performances of PVT/liquid collectors are similar to those of nonselective-type solar thermal absorbers. Observations showed that the stagnation temperature (i.e., the elevated panel temperature in the absence of water flow) of the absorber of a solar thermal collector with a state of-the art spectrally selective coating may reach $220^{\circ} \mathrm{C}$. Since a PVT absorber generally has higher solar reflectance and higher infrared emission than a solar thermal absorber, the stagnation temperature may be lowered to $150^{\circ} \mathrm{C}$. But this is still higher than $135^{\circ} \mathrm{C}$; that is, the temperature that the common encapsulation materials like EVA (ethylene vinyl acetate) resin may withstand [99]. EVA oxidizes rapidly at above $135^{\circ} \mathrm{C}$. 
Charalambous et al. [100] carried out a mathematical analysis on the optimum copper absorber plate configuration having the least material content and thus cost, whilst maintaining high collector efficiency. Both header-and-riser arrangement and serpentine arrangement were studied. It was found that light weight collector design can be achieved using very thin fins and small tubes.

The possible use of copolymer absorber to replace the commonly used metallic sheet-and-tube absorber had been examined extensively [101, 102]. This replacement offers several advantages:

(i) the weight reduction leads to less material utilization and easier installation;

(ii) the manufacturing process is simplified since fewer components are involved;

(iii) the above leads to a reduction in production costs.

However, there are disadvantages such as low thermal conductivity, large thermal expansion, and limited service temperature. On the other hand, the copolymer in use has to be good in physical strength, UV light protected, and chemically stable.

Huang et al. studied a PVT/w collector system complete with DC circulating pump and storage tank [103]. The collector was fabricated by the attachment of commercial PV modules on a corrugated polycarbonate absorber plate with square-shaped box channels.

Cristofari et al. studied the performance of a PVT/w collector with polycarbonate absorber and pc-Si PV modules carrying top and bottom glass sheets [104]. Water in forced flow passed through parallel square channels at very low flow rate and so with negligible pumping power. The system design capacity was based on the hot-water demands for the inhabitants at Ajaccio in France. With the use of a mathematical model, the annual averaged efficiencies of $55.5 \%$ for thermal, $12.7 \%$ for PV, $68.2 \%$ for overall, and $88.8 \%$ for energy saving were obtained. The maximum stagnation temperature at the absorber was found $116.2^{\circ} \mathrm{C}$, which is acceptable. They further developed a collector with copolymer material that reduces the weight by more than half in comparison with the conventional metallic one [105].

Fraisse et al. suggested that PVT/liquid system is very suitable for the low temperature operation of Direct Solar Floor (DSF) system [106]. An application example in the Macon area of France was evaluated with the use of a glazed collector system. With propylene glycol as the coolant, the TRNSYS simulation results gave the annual c-Si cell efficiency as $6.8 \%$, that is, a $28 \%$ drop as compared to a conventional nonintegrated PV module. Without the front glazing, the cell efficiency was increased to $10 \%$ as a result of efficient cooling. It was also found that, in the case of a glazed collector with a conventional control system for DSF, the maximum temperature at the PV modules was above $100^{\circ} \mathrm{C}$ in summer. At this temperature level, the use of EVA in PV modules will be subject to strong risks of degradation. The use of either a-Si cells or unglazed collector was recommended.
(3) PVT Collector Design. Santbergen et al. [107] carried out a numerical study on a forced-flow PVT/w system. Single-glazed sheet-and-tube flat-plate PVT collectors were employed and designed for grid-connected PV system with c-Si PUM cells. Both the annual electrical and thermal efficiencies were found around 15\% lower, when compared to separate conventional PV and conventional solar thermal collector systems. It was suggested that both the electrical and the thermal efficiency can be improved through the use of antireflective coatings. Alternatively, the thermal efficiency can be improved by the application of low-e coating, but at the expenses of the electrical efficiency.

Since long wavelength irradiance with photon energies below the bandgap energy is hardly absorbed at all, the solar absorptance of the solar cells is significantly lower than that of a black absorber (with absorptance $=0.95$ ). Santbergen and van Zolingen [108] also suggested two methods to increase long wavelength absorption:

(i) to use semitransparent solar cells followed by a second absorber and

(ii) to increase the amount of long wavelength irradiance absorption in the back contact of the solar cell.

Computer analysis showed that these two methods are able to achieve an overall absorption of 0.87 and 0.85 , respectively.

Dupeyrat et al. [109] developed a PV cell lamination with Fluorinated Ethylene Propylene (FEP) at the front. This results in an alternative encapsulation with a lower refractive index than glass pane and a lower UV absorbing layer than conventional EVA material. Experimental tests showed an increase of more than $2 \mathrm{~mA} / \mathrm{cm}^{2}$ in generated current density for the PVT module. Finally the developments led to a new covered PVT collector for domestic hot-water application [110]. The c-Si PV cells were directly laminated on an optimized aluminium heat exchanger. The thermal efficiency at zero-reduced temperature was measured 79\% with a corresponding electrical efficiency of $8.8 \%$, leading to a high overall efficiency of almost $88 \%$. This PVT collector in the standard conditions is therefore reaching the highest efficiency level reported in the literature.

Employing a bifacial PV module having two active surfaces can to generate more electric power than the traditional one-surface module. The optical properties of water allow its absorption of light mainly in the infrared region. This is compatible with PV modules using shorter wavelengths in the solar spectra for its electricity conversion. The water absorption only slightly affects the working region of a-Si PV cell (decrease of water transparency at around $950 \mathrm{~nm}$ ), but it strongly absorbs the light with wavelengths above $1100 \mathrm{~nm}$ (the "thermal part" of the solar spectrum). Therefore, a PVT/w collector system with Si bifacial solar PV module can be advantageous. In Mexico, Robles-Ocampo et al. [111] carried out experimental test on a PVT/w system with cSi bifacial PV module in Queretaro. The transparent flat collector was fabricated with a $15 \mathrm{~mm}$ channel underneath a glass cover, which was found better than the plastic cover in terms of service life. Stainless steel mirror reflectors (to 
prevent oxidation in the outdoor environment) were used for illuminating the rear face of the solar cells. Measurements found that the glass water-filled flat collector placed above the PV module reduces the front face efficiency by $10 \%$. When considering the radiation flux incident directly onto the active elements of the hybrid system, the system is able to achieve an electrical efficiency around $16 \%$ and an equivalent thermal efficiency around 50\%.

3.2.2. Building-Integrated Systems (BiPVT/w). The research works on BiPVT/w systems have been less popular than the BiPVT/a systems. Ji et al. carried out a numerical study of the annual performance of a BiPVT/w collector system for use in the residential buildings of Hong Kong [112]. Pump energy was neglected. Assuming perfect bonding of PV encapsulation and copper tubing onto the absorber, the annual thermal efficiencies on the west-facing facade were found $47.6 \%$ and $43.2 \%$ for film cells and c-Si cells, respectively, and the cell efficiencies were $4.3 \%$ and $10.3 \%$. The reductions in space heat gain were estimated $53.0 \%$ and $59.2 \%$, respectively.

Chow et al. studied a BiPVT/w system applicable to multistory apartment building in Hong Kong [113]. The TRNSYS system simulation program was used. They also constructed an experimental BiPVT/w system at a rooftop environmental chamber [114]. The energy efficiencies of thermosyphon and pump circulation modes were compared across the subtropical summer and winter periods. The results show the better energy performance of the thermosyphon operation, with thermal efficiency reaches $39 \%$ at zero-reduced temperature and the corresponding cell efficiency $8.6 \%$. The space cooling load is reduced by $50 \%$ in peak summer. Ji et al. [115] further carried out an optimization study on this type of installation. The appropriate water flow rate, packing factor and connecting pipe diameter were determined.

Based on the above-measured data, Chow et al. also developed an explicit dynamic thermal model of the BiPVT/w collector system [116]. Its annual system performance in Hong Kong reconfirmed the better performance of the natural circulation mode. This is because of the elimination of the pumping power and hence better cost saving [117]. The CPBT was 13.8 years, which is comparable to the stand-alone box channel PVT/w collector system. This BiPVT/w application is able to shorten the CPBT to one-third of the plain BiPV application. The corresponding energy payback time (EPBT) and greenhouse-gas payback time (GPBT) were found 3.8 years and 4.0 years [118]; these are much more favorable than CPBT.

Anderson et al. analyzed the design of a roof-mounted BiPVT/w system [119]. Their BiPVT/w collector prototype was integrated to the standing seam or toughed sheet roof, on which passageways were added to the trough for liquid coolant flow. Their modified Hottel-Whillier model was validated experimentally. The results showed that the key design parameters, like fin efficiency, lamination requirements, and thermal conductivity between the PV module and the supporting structure, affect significantly the electrical and thermal efficiencies. They also suggested that a lower cost material like precoated steel can replace copper or aluminum for thermal absorption since this does not significantly reduce the efficiencies. Another suggestion was to integrate the system "into" (rather than "onto") the roof structure, as the rear air space in the attic can provide a high level of thermal insulation. The effect of nonuniform water flow distribution on electrical conversion performance of BiPVT/w collector of various size was studied by Ghani et al. [120]. The numerical work identified the important role of the array geometry.

Eicker and Dalibard [121] studied the provision of both electrical and cooling energy for buildings. The cooling energy can be used for the direct cooling of activated floors or ceilings. Experimental works with uncovered PVT collector prototypes were carried out to validate a simulation model, which then calculated the night radiative heat exchange with the sky. Large PVT frameless modules were then developed and implemented in a residential zero energy building and tested.

Matuska compared the performance of two types of fin configurations of BiPVT/w collector systems with the BiPV installation using pc-Si cells [122]. Two different European climates and for roof/façade applications were evaluated by computer simulation. Better energy production potential of the BiPVT/w collector systems was confirmedthe results show $15-25 \%$ increase in electricity production in warm climate (Athens) and $8-15 \%$ increase in moderate climate (Prague). The heat production by steady flow forced convection can be up to 10 times higher than the electricity production.

Corbin and Zhai [123] monitored a prototype full-scale $\mathrm{BiPVT} / \mathrm{w}$ collector installed on the roof of a residential dwelling. Measured performance was used to develop a CFD model which was subsequently used in a parametric study to assess the collector performance under a variety of operating conditions. Water temperature observed during testing reaches $57.4^{\circ} \mathrm{C}$ at an ambient temperature of $35.3^{\circ} \mathrm{C}$. The proposed BiPVT/w collector shows a potential for providing the increased electrical efficiency of up to $5.3 \%$ above a naturally ventilated BiPV roof.

\subsection{PVT Refrigeration}

3.3.1. Heat-Pump Integration (PVT/Heat Pump). Conventional air-to-air heat pumps cannot function efficiently in cold winter with extreme low outdoor air temperatures. Bakker et al. [124] introduced a space and tap-water heating system with the use of roof-sized PVT/w array combined with a ground coupled heat pump. The system performance, as applied to one-family Dutch dwelling, was evaluated through TRNSYS simulation. The results showed that the system is able to satisfy all heating demands, and at the same time, to meet nearly all of its electricity consumption, and to keep the long-term average ground temperature constant. The PVT system also requires less roof space and offers architectural uniformity while the required investment is comparable to those of the conventional provisions. 
Bai et al. [125] presented a simulation study of using $\mathrm{PVT} / \mathrm{w}$ collectors as water preheating devices of a solarassisted heat pump (SAHP) system. The system was for application in sports center for swimming pool heating and also for bathroom services. The energy performances of the same system under different climatic conditions, that included Hong Kong and three other cities in France, were analyzed and compared. Economic implications were also determined. The results show that although the system performance in Hong Kong is better than the cities in France, the cost payback period is the longest in Hong Kong since there was no government tax reduction.

Extensive research on PVT/heat pump system with variable pump speed has been conducted in China. Experimental investigations were performed on unglazed PVT evaporator system prototype [126, 127]. Mathematical models based on the distributed parameters approach were developed and validated $[128,129]$. The simulation results show that its performance can be better than the conventional SAHP system. With R-134a as the refrigerant, the PV-SAHP system is able to achieve an annual average COP of 5.93 and PV efficiency $12.1 \%$ [130].

In the warm seasons, glazed PVT collector may not serve well as PVT evaporator. In cold winter however, the outdoor temperature can be much lower than the evaporating temperature of the refrigeration cycle. Then the heat loss at the PV evaporator is no longer negligible. The front cover would be able to improve both the photothermic efficiency and the system COP. Pei et al. concluded that for winter operation, the overall PVT exergy efficiency as well as the COP can be improved in the presence of the glass cover [131]. This is beneficial since the space heating demand is higher in winter.

3.3.2. PVT-Integrated Heat Pipe. These works were basically done in China. Based on the concept of integrating heat pipes and a PVT flat-plate collector into a single unit, Pei et al. $[132,133]$ designed and constructed an experimental rig of heat-pipe PVT (HP-PVT) collector system. The HPPVT collector can be used in cold regions without freezing, and corrosion can be reduced as well. The evaporator section of the heat pipes is connected to the back of the aluminum absorber plate, and the condenser section is inserted into a water box above the absorber plate. The PV cells are laminated onto the surface of the aluminum plate. Detailed simulation models were developed and validated by the experimental findings. Through these, parametric analyses as well as annual system performance for use in three typical climatic areas in China were predicted. The results show that for the HP-PVT system without auxiliary heating equipment, in Hong Kong there are 172 days a year that the hot water can be heated to more than $45^{\circ} \mathrm{C}$ using solar energy. In Lhasa and Beijing, the results are 178 days and 158 days for the same system operation.

In order to solve the nonuniform cooling of solar PV cells and control the operating temperature of solar PV cells conveniently, Wu et al. [134] developed a heatpipe PVT hybrid system by selecting a wick heat pipe to absorb isothermally the excessive heat from solar cells. The PV modules were in a rectangular arrangement, and below which the wick heat-pipe evaporator section is closely attached. The thermal-electric conversion performance was theoretically investigated.

3.3.3. PVT Trigeneration. Calise et al. [135] studied the possible integration of medium-temperature and hightemperature PVT collectors with solar heating and cooling technology, and hence a polygeneration system that produces electricity, space heating and cooling, and domestic hot water. A case study was performed with PVT collectors, single-stage absorption chiller, storage tanks, and auxiliary heaters as the main system components. The system performance was analyzed from both energetic and economic points of view. The economic results show that the system under investigation in Italy can be profitable, provided that an appropriate funding policy is available.

\section{Recent Developments in Concentrator-Type Design}

The use of concentrator-type PVT (or c-PVT) collector can to increase the intensity of solar radiation on the PV cells than the flat-plate collector. The c-PVT collectors are generally classified into three groups: single cells, linear geometry, and densely packed modules. Higher efficiency solar cells that handle higher current can be used, although they are more expensive than the flat-plate module cells. The complex sun tracking driving mechanism also incurs additional costs [136]. But the benefit is that a considerable portion of the cell surfaces can be replaced by low-cost reflector surfaces. Connecting the solar cells in series can to increase the output voltage and decrease the current at a given power output. This reduces the ohmic losses. During operation, nonuniform temperature can exist across the cells. The cell at the highest temperature will limit the efficiency of the whole string [137]. Hence the c-PVT coolant circuit should be designed to keep the cell temperature uniform and relatively low. A precise shape of the reflector surface and an accurate alignment is also essential, particularly when the concentration ratio is high. A precise tracking system is also important.

Refractive lenses and reflector surfaces are commonly in use in c-PVT. Comparatively, lens is lower in weight and material costs. For systems designed for higher concentration, more concentrator material per unit cell/absorber area is in need. Then the use of lenses is more appropriate. However, concentrator systems that utilize lenses are unable to focus scattered light. This limits their usage to places with mostly clear weather. On the other hand, using liquid as the coolant is more effective than using air to obtain better electrical output. These make reflector-type c-PVT systems good for medium- to high-temperature hot-water systems that are required for cooling, desalination, or other industrial processes. At lower operating temperatures, a flatplate collector may have higher efficiency than the c-PVT collector when both are directly facing the sun. But at 
higher temperature differential, the large exposed surface of a flat-plate collector leads to more thermal loss. So the performance gap between the two will diminish when the working temperature gradually increases.

Rosell et al. in Spain constructed a low-concentrating PVT prototype with the combination of flat-plate channelbelow-PV (opaque) collector and linear Fresnel concentrator that worked on two-axis tracking system [138]. The total efficiency was found above $60 \%$ when the concentration ratio was above $6 \mathrm{x}$. Their theoretical analysis reconfirms the importance of the cell-absorber thermal conduction.

Experimental trough c-PVT systems with energy flux ratio in the range of 10-20 were developed and tested in China by Li et al. [139]. Performances of arrays with the use of different solar cells types were compared. Ji et al. [140] also developed steady models of the system and validated them by the measured data. They found that the system performance can be optimized by improving the mirror reflectivity and the thermal solar radiation absorptivity of the lighting plate and by pursuing a suitable focal line with uniform light intensity distribution. Also as a ChinaUK joint research effort, a CPC-based PVT system with a U-pipe was investigated [141]. CPC stands for compound parabolic concentrator. The U-pipe avoids the temperature gradient on the whole absorber and on every block cell and simultaneously produces electricity using the same temperatures. More recently, Zhang et al. [142] proposed a PV system with integrated CPC plate that adopts a low precision solar tracking method; the performance can be better than the fixed installation or the case with periodic adjustment only in several months.

Coventry developed a combined heat and power solar (CHAPS) collector system in Australia [143]. This was a linear trough system designed for single tracking. The c-Si solar cells (at 20\% standard conversion efficiency) in row were bonded to an aluminum receiver and were cooled by water with antifreeze and anticorrosive additives flowing in an internally finned aluminum pipe. Light was focused onto the cells through the use of glass-on-metal parabolic reflectors (92\% reflectance) and at high concentration ratio $(37 \mathrm{x})$. Under typical operating conditions the measurements gave a thermal efficiency around 58\%, electrical efficiency around $11 \%$, and a combined efficiency around $69 \%$.

Kribus et al. [144] developed a miniature concentrating PV system that can be installed on any rooftop. The design is based on a small parabolic dish which is similar to a satellite dish. The system equipments are relatively easy to deliver and handle without the use of special tools. By concentrating sunlight about 500 times, the solar cell area is greatly reduced.

In high-latitude countries like Sweden, the solar radiation is asymmetric over the year because of the high cloud coverage during winter, and thus concentrated to a small angular interval of high irradiation. This makes the use of economical stationary reflectors or concentrators attractive. Cost reduction can be realized by laminating thin aluminum foil on steel substrate. Nilsson et al. [145] carried out experimental tests on an asymmetric compound parabolic reflector system, with two different truncated parabolic reflectors made of anodized aluminum and aluminum laminated steel, respectively. Their measurements confirmed that changing the back reflector from anodized aluminum to aluminum laminated steel does not change the energy output. They also found that the optimal cell position is to face the front reflector, assuming no space restriction. This will result in the lowest cost for electricity generation. For cases with limited roof space, they suggested to place the solar cells on both sides of the absorber. This considers that, once a trough with cells on one side of the absorber is constructed, the cost of adding cells to the other side is relatively low.

A two-stage hybrid device was theoretically studied by Vorobiev et al. [146, 147], with solar cells incorporated on energy flux concentrator and heat-to-electric/mechanic energy converter. Two option cases were investigated:

(i) system with the separation of "thermal solar radiation", and

(ii) system without solar spectrum division and solar cell operating at high temperature.

The first case allows the solar cell to operate at a low ambient temperature, but then requires the production of a new kind of solar cell which does not absorb or dissipate solar radiation as infrared. The calculations showed that with a concentration as high as $1500 \mathrm{x}$, the total conversion efficiency could reach 35-40\%. The solar cell in the second option is subject to concentrated sunlight. It was found that with the use of GaAs-based single-junction cell having room temperature efficiency at $24 \%$ and a concentrator at 50x, the total conversion efficiency is around $25-30 \%$. If a higher concentration is used, the efficiency can be even higher.

Jiang et al. [148] introduced a two-stage parabolic trough concentrating PVT system, which contains a concentrator, a spectral beam splitting filter, an evacuated collector tube, and the solar cell components. The nondimensional optical model with the focal length of the concentrator as the characteristic length has been developed to analyze the properties of the concentrating system using the beam splitting filter. The geometry concentration ratio and the size of solar image at different structure parameters have been obtained. It is shown that using the filter the heat load of the cell can be reduced by $20.7 \%$. Up to $10.5 \%$ of the total incident solar energy can be recovered by the receiver, and the overall optical efficiency in theory is about 0.764 .

Kostic et al. [149] studied the influence of reflectance from flat-plate solar radiation concentrators made of aluminum sheet and aluminum foil on energy efficiency of PVT collector. The total reflectance from concentrators made of aluminum sheet and aluminum foil is almost the same, but specular reflectance (which is bigger in concentrators made of aluminum foil) results in an increase of solar radiation intensity concentration factor. The total energy generated by c-PVT collector made of aluminum foil in optimal position is higher than the total energy generated by those made of aluminum sheet.

The basic feature of an STPV (solar thermophotovoltaic) is in the use of high temperature emitter as an intermediate element that absorbs concentrated solar light and emits photonic energy to solar cells through which the thermal 
radiation energy is converted to electricity. Compared with the solar cells, the STPV system can utilize the concentrated solar energy sufficiently. It conveniently adjusts the spectral feature of photons released from the emitter corresponding to the bandgaps of solar cells in the system by controlling the emitter temperature and/or installing the spectral filter. Xuan et al. [150] established the design and optimization method of STPV systems by taking into account the energy transport and/or conversion processes among the solar concentrator, the emitter, the spectral filter, the solar cells, and the cooling subsystem. The effects of the nonparallelism of sun rays, aperture ratios, and the tracking error on concentration capacity were investigated. The emitters made of different materials and with different configurations were numerically analyzed. The effects of concentration ratio, spectral characteristic of the filter, series and shunt resistance of the cell, and the performance of the cooling system on the STPV systems were discussed. Compared with the one-dimensional photonic filer, the optimized nonperiodic filter has a better performance. A high-performance cooling system is required to keep the cell temperature below $50^{\circ} \mathrm{C}$.

As an attempt to improve the system efficiency of concentrating photovoltaics (CPVs), an investigation has been done by Kosmadakis et al. [151] into the technical aspects as well as the cost analysis, by combining the technologies of the CPV and the organic Rankine cycles (ORCs). The heat rejected from the CPV is recovered from the ORC, in order to increase the total electric power output. The findings constitute evidence that the CPV-ORC system can be an alternative for recovering the heat from concentrating PVs. Nevertheless, the mechanical power produced from the expander of the ORC can be used in other applications as well.

Huang et al. [152] suggested a PVT system based on organic photovoltaics (OPVs). The OPV cells were fabricated onto one-half of a tubular light pipe inside which the silicone oil was flowed. This allows solar energy in the visible wavelengths to be effectively converted into electricity by photocell while simultaneously the silicone oil captures the infrared radiation part of the spectrum as heat energy. The oil filled tube acts as a passive optical element that concentrates the light into the PV and thereby increases its overall efficiency.

While silicon-based PV technology has many physical barriers, it is expected that the future PVT developments will be closely linked to the breakthroughs in solar cell technology. The next generation solar cells such as polymer, nanocrystalline, and dye-sensitized solar cells will be less expensive, flexible, compact, lightweight, and efficient. Take dye-sensitized solar cells (DSSCs) as an example, the operation does not need the $\mathrm{p}-\mathrm{n}$ junction but mimics the principle of natural photosynthesis. It is composed of a porous layer of titanium dioxide nanoparticles, covered with a molecular dye that absorbs sunlight, like the chlorophyll in green leaves. The DSSCs today convert about 11 to $12 \%$ of the sunlight into electricity. The use of hybrid $\mathrm{ZnO} / \mathrm{TiO}_{2}$ photoanodes will be able to utilize the high electron transport rate of $\mathrm{ZnO}$ and the high electron injection efficiency and stability of $\mathrm{TiO} 2$ materials [153].

\section{Miscellaneous Developments in Recent Years}

5.1. Autonomous Applications. Desalination is a process to produce the distilled water from brackish/saline water by means of solar still. Solar distillation of brackish water is a good option to obtain fresh water in view of its simple technology and low energy operation. A proposed design of PVT-integrated active solar still was tested in India by Kumar and Tiwari [154-156]. This PVT active solar still is self-sustainable and can be used in remote areas. Compared with a passive solar still, the daily distillate yield was found 3.5 times higher, and $43 \%$ of the pumping power can be saved. Based on $0.05 \mathrm{~m}$ water depth, the range of CPBT can be shortened from 3.3-23.9 years to 1.1-6.2 years (depending on the selling price of distilled water) and the EPBT from 4.7 years to 2.9 years. The hybrid active solar still is able to provide higher electrical and overall thermal efficiency, which is about $20 \%$ higher than the passive solar still. On the other hand, Gaur and Tiwari [157] conducted a numerical study to optimize the number of collectors for PVT/w hybrid active solar still. The number of PVT collectors connected in series has been integrated with the basin of a solar still.

Another potential application lies in crop drying, which is the process of removing excess moisture from crop produced through evaporation, either by natural or forced convection mode. Tiwari et al. developed a PVT mixed mode dryer together with an analytical model for performance analysis [158]. The experimental tests were executed for the forced convection mode under no load conditions. The annual gains for different Indian cities were evaluated and the results show that Jodhpur is the best place for the installation of this type of PVT dryer.

5.2. High Temperature Applications. Mittelman et al. [159] studied the application of c-PVT system in a LiBr absorption chiller designed for single effect. In the theoretical analysis, the desorber inlet temperature was set in the range of 65$120^{\circ} \mathrm{C}$ and without thermal storage. The PV module was based on triple-junction cells with a nominal conversion efficiency of $37 \%$. A typical dish concentrator with an $85 \%$ optical efficiency was used. The results showed that the loss in cell efficiency owing to the increase in operation temperature was insignificant. Under a reasonably range of economic conditions, the c-PVT cooling system can be comparable to, and sometimes even better than, a conventional cooling system.

A c-PVT water desalination system was also proposed by Mittelman et al. [160], in which a c-PVT collector field was to couple to a large-scale multiple-effect evaporation thermal desalination system. Small dish concentrator type was used in the numerical analysis. The vapor formed in each evaporator condenses in the next (lower temperature) effect and thus provides the heat source for further evaporation. Additional feed preheating is to be provided by vapor process bleeding from each effect. The range of top brine temperature is from 60 to $80^{\circ} \mathrm{C}$. Through numerical analysis, this approach was found competitive relative to other solar-driven desalination systems and even relative to the conventional reverse-osmosis desalination. Because of the higher ratio of electricity to heat 
generation, the high concentration option with the use of advanced solar cells can be advantageous.

5.3. Commercial Aspects. The commercial markets for both solar thermal and photovoltaic are growing rapidly. It is expected that the PVT products, once become mature, would experience a similar trend of growth. In future, the market share might be even larger than that for solar thermal collectors. The higher energy output characteristics of the PVT collector suit better the increasing demands on low-energy or even zero-carbon buildings. Nevertheless, although there are plenty reported literatures on the theoretical and experimental findings of PVT collector systems, those reporting on full-scale application and longterm monitoring have been scarce [161]. The number of commercial systems in practical services remains small. The majority involves flat-plate collectors but only with limited service life. The operating experiences are scattered. In the inventory of IEA Solar Heating and Cooling Task 35, over 50 PVT projects have been identified in the past 20 years. Less than twenty of these projects belong to the PVT/w category which is supposed to have better application potential. On the other hand, while most projects were in Europe such as UK and Netherlands, there have been projects realized in Thailand, in which large-scale glazed a-Si PVT/w systems were installed at hospital and government buildings [162]. It is important to have full documentation of the initial testing and commissioning, as well as the long-term monitoring of the real systems performance, including the operating experiences and the problems encountered. Developments in the balance of system are also important-for example the improvement works in power quality and power factor in PV inverter design [163]. The improvements in power supply stability with power conditioner and better integration of renewable energy sources on to utility grid have been other key research areas [164].

Standard testing procedures for PVT commercial products are so far incomplete. In essence, the performance of PVT commercial products can be tested either outdoor or indoor. The outdoor test needs to be executed in steady conditions of fine weather, which should be around noon hours and preferably with clear sky and no wind. This can be infrequent; say for Northern Europe, it may take six months to acquire the efficiency curve [165]. Indoor test can be quicker and provides repeatable results. To make available an internationally accepted testing standard is one important step for promoting the PVT products.

Although there have been an obvious increase in academic publications in hybrid PVT technology in recent years, many key issues related to the commercialization of PVT products are still not resolved. The lack of economic viability, public awareness, product standardization, warranties and performance certification, installation training, and experiences are the barriers. It is important for the reliability of the technology to be thoroughly assessed.

\section{Conclusion}

Global climate change and fuel supply security have led to the fast development in renewable technology, including solar energy applications. The installations of solar thermal and PV electricity generation devices are growing rapidly and these lead to an increase in the demand of PVT collector system. PVT products have much shorter CPBT than the PV counterpart. Hence PVT (rather than PV) as a renewable energy technology is expected to first become competitive with the conventional power generating systems.

In the past decades, the performance of various PVT collector types had been studied theoretically, numerically, and experimentally. This paper serves to review the endeavor in the past years. While in the early works the research efforts were on the consolidation of the conceptual ideas and the feasibility study on basic PVT collector designs, the PVT studies from the 90s onward have been more related to the collector design improvement and economical/environmental performance evaluation. There were more rigorous numerical analyses of the energy and fluid flow phenomena on conventional collectors with an experimental validation. The ideas of building-integrated design emerged and the demonstration projects were reported. Since the turn of century, the focus has been generally shifted towards the development of complimentary products, innovative systems, testing procedures, and design optimization. The marketing potential and justification on various collector designs and system applications have been evaluated through user feedback, life cycle cost, and/or embodied energy evaluations. The computational analyses become more comprehensive with the use of powerful analytical tools. There have been increased uses of explicit dynamic modeling techniques and also public domain simulation programs, including CFD codes. The evaluation has been extended to geographical comparison of long-term performance based on typical year round weather data on one hand and the second-law thermodynamic assessment on the other. International research collaborations and related activities have been increasing.

Despite the sharp increase in academic activities, the developments of commercial products and real system applications are still limited. The issues of investment costs and product reliability are to be fully attended. More efforts must be on the identification of suitable product materials, manufacturing techniques, testing and training requirements, potential customers, market strength, and so on.

\section{Acknowledgment}

The research work described in this paper was fully supported by the France/Hong Kong Joint Research Scheme (project no. F_HK05/11T).

\section{References}

[1] M. Wolf, "Performance analyses of combined heating and photovoltaic power systems for residences," Energy Conversion, vol. 16, no. 1-2, pp. 79-90, 1976.

[2] E. C. Kern and M. C. Russell, "Combined photovoltaic and thermal hybrid collector systems," in Proceedings of the 13th IEEE Photovoltaic Specialists, pp. 1153-1157, Washington DC, USA, June 1978. 
[3] L. W. Florschuetz, "Extension of the Hottel-Whillier model to the analysis of combined photovoltaic/thermal flat plate collectors," Solar Energy, vol. 22, no. 4, pp. 361-366, 1979.

[4] T. T. Chow, "A review on photovoltaic/thermal hybrid solar technology," Applied Energy, vol. 87, no. 2, pp. 365-379, 2010.

[5] C. H. Cox III and P. Raghuraman, "Design considerations for flat-plate-photovoltaic/thermal collectors," Solar Energy, vol. 35, no. 3, pp. 227-241, 1985.

[6] B. Lalović, Z. Kiss, and H. Weakliem, "A hybrid amorphous silicon photovoltaic and thermal solar collector," Solar Cells, vol. 19, no. 2, pp. 131-138, 1986.

[7] H. P. Garg and R. S. Adhikari, "Conventional hybrid photovoltaic/thermal (PV/T) air heating collectors: steadystate simulation," Renewable Energy, vol. 11, no. 3, pp. 363 385, 1997.

[8] H. P. Garg and R. S. Adhikari, "Optical design calculations for CPCS," Energy, vol. 23, no. 10, pp. 907-909, 1998.

[9] H. P. Garg and R. S. Adhikari, "Performance analysis of a hybrid photovoltaic/thermal (PV/T) collector with integrated CPC troughs," International Journal of Energy Research, vol. 23, no. 15, pp. 1295-1304, 1999.

[10] K. Sopian, K. S. Yigit, H. T. Liu, S. Kakaç, and T. N. Veziroglu, "Performance analysis of photovoltaic thermal air heaters," Energy Conversion and Management, vol. 37, no. 11, pp. 1657-1670, 1996.

[11] K. Sopian, H. T. Liu, S. Kakac, and T. N. Veziroglu, "Performance of a double pass photovoltaic thermal solar collector suitable for solar drying systems," Energy Conversion and Management, vol. 41, no. 4, pp. 353-365, 2000.

[12] J. Prakash, "Transient analysis of a photovoltaic-thermal solar collector for co-generation of electricity and hot air/water," Energy Conversion and Management, vol. 35, no. 11, pp. 967$972,1994$.

[13] T. Bergene and O. M. Løvvik, "Model calculations on a flatplate solar heat collector with integrated solar cells," Solar Energy, vol. 55, no. 6, pp. 453-462, 1995.

[14] D. W. de Vries, Design of a photovoltaic/thermal combi-panel [Ph.D. thesis], Eindhoven Technical University, Eindhoven, The Netherlands, 1998.

[15] T. Fujisawa and T. Tani, "Annual exergy evaluation on photovoltaic-thermal hybrid collector," Solar Energy Materials and Solar Cells, vol. 47, no. 1-4, pp. 135-148, 1997.

[16] B. Norton and J. E. J. Edmonds, "Aqueous propylene-glycol concentrations for the freeze protection of thermosyphon solar energy water heaters," Solar Energy, vol. 47, no. 5, pp. 375-382, 1991.

[17] G. Rockendorf, R. Sillmann, L. Podlowski, and B. Litzenburger, "PV-hybrid and thermoelectric collectors," Solar Energy, vol. 67, no. 4-6, pp. 227-237, 1999.

[18] M. W. Davis, A. H. Fanney, and B. P. Dougherty, "Prediction of building integrated photovoltaic cell temperatures," Journal of Solar Energy Engineering, vol. 123, no. 3, pp. 200-210, 2001.

[19] B. Moshfegh and M. Sandberg, "Flow and heat transfer in the air gap behind photovoltaic panels," Renewable and Sustainable Energy Reviews, vol. 2, no. 3, pp. 287-301, 1998.

[20] J. A. Clarke, J. W. Hand, C. M. Johnstone, N. Kelly, and P. A. Strachan, "Photovoltaic-integrated building facades," Renewable Energy, vol. 8, no. 1-4, pp. 475-479, 1996.

[21] B. J. Brinkworth, R. H. Marshall, and Z. Ibarahim, "A validated model of naturally ventilated PV cladding," Solar Energy, vol. 69, no. 1, pp. 67-81, 2000.

[22] J. C. Hollick, "Solar cogeneration panels," Renewable Energy, vol. 15, no. 1, pp. 195-200, 1998.
[23] A. Akbarzadeh and T. Wadowski, "Heat pipe-based cooling systems for photovoltaic cells under concentrated solar radiation," Applied Thermal Engineering, vol. 16, no. 1, pp. 81-87, 1996.

[24] A. Luque, G. Sala, J. C. Arboiro, T. Bruton, D. Cunningham, and N. Mason, "Some results of the EUCLIDES photovoltaic concentrator prototype," Progress in Photovoltaics: Research and Applications, vol. 5, no. 3, pp. 195-212, 1997.

[25] S. Ito, N. Miura, and K. Wang, "Performance of a heat pump using direct expansion solar collectors," Solar Energy, vol. 65, no. 3, pp. 189-196, 1999.

[26] S. Ito and N. Miura, "Photovoitaic and thermal hybrid systems," in Proceedings of the Asia-Pacific Conference of International Solar Energy Society, pp. 73-78, Gwangju, South Korea, October 2004.

[27] P. Affolter, D. Ruoss, P. Toggweiler, and B. A. Haller, "New Generation of Hybrid Solar Collectors," Final Report DIS 56360/16868, Swiss Federal Office for Energy, 2000.

[28] IEA, "Photovoltaic/thermal solar energy systems: status of the technology and roadmap for future development," Task 7 Report, International Energy Agency, PVPS T7-10, 2002.

[29] A. A. Hegazy, "Comparative study of the performances of four photovoltaic/thermal solar air collectors," Energy Conversion and Management, vol. 41, no. 8, pp. 861-881, 2000.

[30] Y. Tripanagnostopoulos, T. Nousia, M. Souliotis, and P. Yianoulis, "Hybrid photovoltaic/thermal solar systems," Solar Energy, vol. 72, no. 3, pp. 217-234, 2002.

[31] J. K. Tonui and Y. Tripanagnostopoulos, "Air-cooled PV/T solar collectors with low cost performance improvements," Solar Energy, vol. 81, no. 4, pp. 498-511, 2007.

[32] Y. Tripanagnostopoulos, "Aspects and improvements of hybrid photovoltaic/thermal solar energy systems," Solar Energy, vol. 81, no. 9, pp. 1117-1131, 2007.

[33] A. Tiwari, M. S. Sodha, A. Chandra, and J. C. Joshi, "Performance evaluation of photovoltaic thermal solar air collector for composite climate of India," Solar Energy Materials and Solar Cells, vol. 90, no. 2, pp. 175-189, 2006.

[34] A. Tiwari, P. Barnwal, G. S. Sandhu, and M. S. Sodha, "Energy metrics analysis of hybrid-photovoltaic (PV) modules," Applied Energy, vol. 86, no. 12, pp. 2615-2625, 2009.

[35] V. Raman and G. N. Tiwari, "A comparison study of energy and exergy performance of a hybrid photovoltaic double-pass and single-pass air collector," International Journal of Energy Research, vol. 33, no. 6, pp. 605-617, 2009.

[36] A. S. Joshi, I. Dincer, and B. V. Reddy, "Thermodynamic assessment of photovoltaic systems," Solar Energy, vol. 83, no. 8, pp. 1139-1149, 2009.

[37] S. Nayak and G. N. Tiwari, "Energy metrics of photovoltaic/thermal and earth air heat exchanger integrated greenhouse for different climatic conditions of India," Applied Energy, vol. 87, no. 10, pp. 2984-2993, 2010.

[38] S. Dubey, G. S. Sandhu, and G. N. Tiwari, "Analytical expression for electrical efficiency of PV/T hybrid air collector," Applied Energy, vol. 86, no. 5, pp. 697-705, 2009.

[39] S. Dubey, S. C. Solanki, and A. Tiwari, "Energy and exergy analysis of PV/T air collectors connected in series," Energy and Buildings, vol. 41, no. 8, pp. 863-870, 2009.

[40] S. C. Solanki, S. Dubey, and A. Tiwari, "Indoor simulation and testing of photovoltaic thermal (PV/T) air collectors," Applied Energy, vol. 86, no. 11, pp. 2421-2428, 2009.

[41] Y. B. Assoa, C. Menezo, G. Fraisse, R. Yezou, and J. Brau, "Study of a new concept of photovoltaic-thermal hybrid collector," Solar Energy, vol. 81, no. 9, pp. 1132-1143, 2007. 
[42] Y. Sukamongkol, S. Chungpaibulpatana, B. Limmeechokchai, and P. Sripadungtham, "Condenser heat recovery with a PV/T air heating collector to regenerate desiccant for reducing energy use of an air conditioning room," Energy and Buildings, vol. 42, no. 3, pp. 315-325, 2010

[43] A. H. H. Ali, M. Ahmed, and M. S. Youssef, "Characteristics of heat transfer and fluid flow in a channel with singlerow plates array oblique to flow direction for photovoltaic/thermal system," Energy, vol. 35, no. 9, pp. 3524-3534, 2010.

[44] R. Kumar and M. A. Rosen, "Performance evaluation of a double pass $\mathrm{PV} / \mathrm{T}$ solar air heater with and without fins," Applied Thermal Engineering, vol. 31, no. 8-9, pp. 1402-1410, 2011.

[45] M. D. Bazilian and D. Prasad, "Modelling of a photovoltaic heat recovery system and its role in a design decision support tool for building professionals," Renewable Energy, vol. 27, no. 1, pp. 57-68, 2002.

[46] B. P. Cartmell, N. J. Shankland, D. Fiala, and V. Hanby, "A multi-operational ventilated photovoltaic and solar air collector: application, simulation and initial monitoring feedback," Solar Energy, vol. 76, no. 1-3, pp. 45-53, 2004.

[47] L. Mei, D. Infield, U. Eicker, and V. Fux, "Thermal modelling of a building with an integrated ventilated PV façade," Energy and Buildings, vol. 35, no. 6, pp. 605-617, 2003.

[48] D. Infield, L. Mei, and U. Eicker, "Thermal performance estimation for ventilated PV facades," Solar Energy, vol. 76, no. 1-3, pp. 93-98, 2004.

[49] M. Sandberg and B. Moshfegh, "Buoyancy-induced air flow in photovoltaic facades effect of geometry of the air gap and location of solar cell modules," Building and Environment, vol. 37, no. 3, pp. 211-218, 2002.

[50] G. Mittelman, A. Alshare, and J. H. Davidson, "A model and heat transfer correlation for rooftop integrated photovoltaics with a passive air cooling channel," Solar Energy, vol. 83, no. 8, pp. 1150-1160, 2009.

[51] G. Gan, "Effect of air gap on the performance of buildingintegrated photovoltaics," Energy, vol. 34, no. 7, pp. 913-921, 2009.

[52] O. Zogou and H. Stapountzis, "Flow and heat transfer inside a PV/T collector for building application," Applied Energy, vol. 91, no. 1, pp. 103-115, 2012.

[53] Y. Chen, A. K. Athienitis, and K. Galal, "Modeling, design and thermal performance of a BIPV/T system thermally coupled with a ventilated concrete slab in a low energy solar house: part 1, BIPV/T system and house energy concept," Solar Energy, vol. 84, no. 11, pp. 1892-1907, 2010.

[54] Y. Chen, K. Galal, and A. K. Athienitis, "Modeling, design and thermal performance of a BIPV/T system thermally coupled with a ventilated concrete slab in a low energy solar house: part 2, ventilated concrete slab," Solar Energy, vol. 84, no. 11, pp. 1908-1919, 2010.

[55] A. K. Athienitis, J. Bambara, B. O’Neill, and J. Faille, "A prototype photovoltaic/thermal system integrated with transpired collector," Solar Energy, vol. 85, no. 1, pp. 139-153, 2011.

[56] S. Pantic, L. Candanedo, and A. K. Athienitis, "Modeling of energy performance of a house with three configurations of building-integrated photovoltaic/thermal systems," Energy and Buildings, vol. 42, no. 10, pp. 1779-1789, 2010.

[57] R. H. Crawford, G. J. Treloar, R. J. Fuller, and M. Bazilian, "Life-cycle energy analysis of building integrated photovoltaic systems (BiPVs) with heat recovery unit," Renewable and Sustainable Energy Reviews, vol. 10, no. 6, pp. 559-575, 2006.

[58] B. Agrawal and G. N. Tiwari, "Optimizing the energy and exergy of building integrated photovoltaic thermal (BIPVT) systems under cold climatic conditions," Applied Energy, vol. 87, no. 2, pp. 417-426, 2010.

[59] B. Agrawal and G. N. Tiwari, "Life cycle cost assessment of building integrated photovoltaic thermal (BIPVT) systems," Energy and Buildings, vol. 42, no. 9, pp. 1472-1481, 2010.

[60] J. Jie, H. Wei, and H. N. Lam, "The annual analysis of the power output and heat gain of a PV-wall with different integration mode in Hong Kong," Solar Energy Materials and Solar Cells, vol. 71, no. 4, pp. 435-448, 2002.

[61] H. Yang, J. Burnett, and Z. Zhu, "Building-integrated photovoltaics: effect on the cooling load component of building façades," Building Services Engineering Research and Technology, vol. 22, no. 3, pp. 157-165, 2001.

[62] T. T. Chow, J. W. Hand, and P. A. Strachan, "Buildingintegrated photovoltaic and thermal applications in a subtropical hotel building," Applied Thermal Engineering, vol. 23, no. 16, pp. 2035-2049, 2003.

[63] J. Ji, B. Jiang, H. Yi, T. T. Chow, W. He, and G. Pei, "An experimental and mathematical study of efforts of a novel photovoltaic-Trombe wall on a test room," International Journal of Energy Research, vol. 32, no. 6, pp. 531-542, 2008.

[64] A. Fieber, H. Gajbert, H. Hakansson, J. Nilsson, T. Rosencrantz, and B. Karlsson, "Design, building integration and performance of a hybrid solar wall element," in Proceedings of the ISES Solar World Congress, Gothenburg, Sweden, 2003.

[65] H. Davidsson, B. Perers, and B. Karlsson, "Performance of a multifunctional PV/T hybrid solar window," Solar Energy, vol. 84, no. 3, pp. 365-372, 2010.

[66] H. Davidsson, B. Perers, and B. Karlsson, "System analysis of a multifunctional PV/T hybrid solar window," Solar Energy, vol. 86, no. 3, pp. 903-910, 2012.

[67] T. T. Chow, K. F. Fong, W. He, Z. Lin, and A. L. S. Chan, "Performance evaluation of a PV ventilated window applying to office building of Hong Kong," Energy and Buildings, vol. 39, no. 6, pp. 643-650, 2007.

[68] T. T. Chow, G. Pei, L. S. Chan, Z. Lin, and K. F. Fong, "A comparative study of PV glazing performance in warm climate," Indoor and Built Environment, vol. 18, no. 1, pp. 3240, 2009.

[69] T. T. Chow, Z. Qiu, and C. Li, "Potential application of "seethrough" solar cells in ventilated glazing in Hong Kong," Solar Energy Materials and Solar Cells, vol. 93, no. 2, pp. 230 238, 2009.

[70] T. T. Chow, Z. Qiu, and C. Li, "Performance evaluation of PV ventilated glazing," in Proceedings of the Building Simulation 2009, 11th International Building Performance Simulation Association Conference, Glasgow, UK, July 2009.

[71] H. A. Zondag, D. W. de Vries, W. G. J. van Helden, R. J. C. van Zolingen, and A. A. van Steenhoven, "The thermal and electrical yield of a PV-thermal collector," Solar Energy, vol. 72, no. 2, pp. 113-128, 2002.

[72] H. A. Zondag, D. W. de Vries, W. G. J. van Helden, R. J. C. van Zolingen, and A. A. van Steenhoven, "The yield of different combined PV-thermal collector designs," Solar Energy, vol. 74, no. 3, pp. 253-269, 2003.

[73] B. Sandnes and J. Rekstad, "A photovoltaic/thermal (PV/T) collector with a polymer absorber plate. Experimental study and analytical model," Solar Energy, vol. 72, no. 1, pp. 63-73, 2002. 
[74] T. T. Chow, "Performance analysis of photovoltaic-thermal collector by explicit dynamic model," Solar Energy, vol. 75, no. 2, pp. 143-152, 2003.

[75] R. Zakharchenko, L. Licea-Jiménez, S. A. Pérez-García et al., "Photovoltaic solar panel for a hybrid PV/Thermal system," Solar Energy Materials and Solar Cells, vol. 82, no. 1-2, pp. 253-261, 2004

[76] S. Dubey and G. N. Tiwari, "Thermal modeling of a combined system of photovoltaic thermal (PV/T) solar water heater," Solar Energy, vol. 82, no. 7, pp. 602-612, 2008.

[77] S. A. Kalogirou, "Use a TRNSYS for modelling and simulation of a hybrid pv-thermal solar system for Cyprus," Renewable Energy, vol. 23, no. 2, pp. 247-260, 2001.

[78] S. A. Kalogirou and Y. Tripanagnostopoulos, "Hybrid PV/T solar systems for domestic hot water and electricity production," Energy Conversion and Management, vol. 47, no. 18-19, pp. 3368-3382, 2006.

[79] S. A. Kalogirou and Y. Tripanagnostopoulos, "Industrial application of PV/T solar energy systems," Applied Thermal Engineering, vol. 27, no. 8-9, pp. 1259-1270, 2007.

[80] E. Erdil, M. Ilkan, and F. Egelioglu, "An experimental study on energy generation with a photovoltaic (PV)-solar thermal hybrid system," Energy, vol. 33, no. 8, pp. 1241-1245, 2008.

[81] G. Vokas, N. Christandonis, and F. Skittides, "Hybrid photovoltaic-thermal systems for domestic heating and cooling — a theoretical approach," Solar Energy, vol. 80, no. 5, pp. 607-615, 2006.

[82] L. T. Kostić, T. M. Pavlović, and Z. T. Pavlović, "Optimal design of orientation of PV/T collector with reflectors," Applied Energy, vol. 87, no. 10, pp. 3023-3029, 2010.

[83] H. Saitoh, Y. Hamada, H. Kubota et al., "Field experiments and analyses on a hybrid solar collector," Applied Thermal Engineering, vol. 23, no. 16, pp. 2089-2105, 2003.

[84] J. Zhao, Y. Song, W. H. Lam et al., "Solar radiation transfer and performance analysis of an optimum photovoltaic/thermal system," Energy Conversion and Management, vol. 52, no. 2, pp. 1343-1353, 2011.

[85] T. T. Chow, G. Pei, K. F. Fong, Z. Lin, A. L. S. Chan, and J. Ji, "Energy and exergy analysis of photovoltaic-thermal collector with and without glass cover," Applied Energy, vol. 86, no. 3, pp. 310-316, 2009.

[86] J. H. Kim and J. T. Kim, "Comparison of electrical and thermal performances of glazed and unglazed PVT collectors," International Journal of Photoenergy, vol. 2012, Article ID 957847, 7 pages, 2012.

[87] J. H. Kim and J. T. Kim, "The experimental performance of an unglazed PVT collector with two different absorber types," International Journal of Photoenergy, vol. 2012, Article ID 312168, 6 pages, 2012.

[88] S. Dubey and G. N. Tiwari, "Analysis of PV/T flat plate water collectors connected in series," Solar Energy, vol. 83, no. 9, pp. 1485-1498, 2009.

[89] A. Tiwari, S. Dubey, G. S. Sandhu, M. S. Sodha, and S. I. Anwar, "Exergy analysis of integrated photovoltaic thermal solar water heater under constant flow rate and constant collection temperature modes," Applied Energy, vol. 86, no. 12, pp. 2592-2597, 2009.

[90] R. Naewngerndee, E. Hattha, K. Chumpolrat, T. Sangkapes, J. Phongsitong, and S. Jaikla, "Finite element method for computational fluid dynamics to design photovoltaic thermal (PV/T) system configuration," Solar Energy Materials and Solar Cells, vol. 95, no. 1, pp. 390-393, 2011.
[91] M. Rosa-Clot, P. Rosa-Clot, and G. M. Tina, "TESPI: thermal electric solar panel integration," Solar Energy, vol. 85, no. 10, pp. 2433-2442, 2011.

[92] T. T. Chow, W. He, and J. Ji, "Hybrid photovoltaicthermosyphon water heating system for residential application," Solar Energy, vol. 80, no. 3, pp. 298-306, 2006.

[93] T. T. Chow, J. Ji, and W. He, "Photovoltaic-thermal collector system for domestic application," Journal of Solar Energy Engineering, vol. 129, no. 2, pp. 205-209, 2007.

[94] W. He, T. T. Chow, J. Ji, J. Lu, G. Pei, and L. S. Chan, "Hybrid photovoltaic and thermal solar-collector designed for natural circulation of water," Applied Energy, vol. 83, no. 3, pp. 199210, 2006.

[95] J. Ji, J. Han, T. T. Chow, C. Han, J. Lu, and W. He, "Effect of flow channel dimensions on the performance of a box-frame photovoltaic/thermal collector," Proceedings of the Institution of Mechanical Engineers A, vol. 220, no. 7, pp. 681-688, 2006.

[96] J. Ji, J. P. Lu, T. T. Chow, W. He, and G. Pei, "A sensitivity study of a hybrid photovoltaic/thermal water-heating system with natural circulation," Applied Energy, vol. 84, no. 2, pp. 222-237, 2007.

[97] T. T. Chow, W. He, J. Ji, and A. L. S. Chan, "Performance evaluation of photovoltaic-thermosyphon system for subtropical climate application," Solar Energy, vol. 81, no. 1, pp. 123-130, 2007.

[98] P. Affolter, W. Eisenmann, H. Fechner et al., PVT Roadmap: A European Guide for the Development and Market Introduction of PV-Thermal Technology, ECN, 2007.

[99] H. A. Zondag and W. G. J. van Helden, "Stagnation temperature in PVT collector," Report ECN-RX-02-045, 2002, http://www.ecn.nl/library/reports/2002/rx02045.html.

[100] P. G. Charalambous, S. A. Kalogirou, G. G. Maidment, and K. Yiakoumetti, "Optimization of the photovoltaic thermal (PV/T) collector absorber," Solar Energy, vol. 85, no. 5, pp. 871-880, 2011.

[101] M. Meir and J. Rekstad, "Der solarnor kunststoffkollektorthe development of a polymer collector with glazing," in Proceedings of the Polymeric Solar Material, Erstes Leobener Symposium "Solartechnik-Neue moglichkeiten fur die Kunststoffbranche", pp. II. 1-II. 8., Polymer Competence Center Leoben, Leoben, Austria, October 2003.

[102] P. Papillon, G. Wallner, and M. Kohl, "Polymeric materials in solar thermal applications," Solar Heating and Cooling Program, Task 39, International Energy Agency, http://www.iea-shc.org/task39.

[103] B. J. Huang, T. H. Lin, W. C. Hung, and F. S. Sun, "Performance evaluation of solar photovoltaic/thermal systems," Solar Energy, vol. 70, no. 5, pp. 443-448, 2001.

[104] C. Cristofari, G. Notton, and J. L. Canaletti, "Thermal behavior of a copolymer PV/Th solar system in low flow rate conditions," Solar Energy, vol. 83, no. 8, pp. 1123-1138, 2009.

[105] C. Cristofari, J. L. Canaletti, G. Notton, and C. Darras, "Innovative patented PV/TH solar collector: optimization and performance evaluation," Energy Procedia, vol. 14, pp. 235-240, 2012.

[106] G. Fraisse, C. Ménézo, and K. Johannes, "Energy performance of water hybrid PV/T collectors applied to combisystems of direct solar floor type," Solar Energy, vol. 81, no. 11, pp. 1426-1438, 2007.

[107] R. Santbergen, C. C. M. Rindt, H. A. Zondag, and R. J. C. van Zolingen, "Detailed analysis of the energy yield of systems with covered sheet-and-tube PVT collectors," Solar Energy, vol. 84, no. 5, pp. 867-878, 2010. 
[108] R. Santbergen and R. J. C. van Zolingen, "Modeling the thermal absorption factor of photovoltaic/thermal combipanels," Energy Conversion and Management, vol. 47, no. 20, pp. 3572-3581, 2006.

[109] P. Dupeyrat, C. Ménézo, H. Wirth, and M. Rommel, "Improvement of PV module optical properties for PVthermal hybrid collector application," Solar Energy Materials and Solar Cells, vol. 95, no. 8, pp. 2028-2036, 2011.

[110] P. Dupeyrat, C. Ménézo, M. Rommel, and H. M. Henning, "Efficient single glazed flat plate photovoltaic-thermal hybrid collector for domestic hot water system," Solar Energy, vol. 85, no. 7, pp. 1457-1468, 2011.

[111] B. Robles-Ocampo, E. Ruíz-Vasquez, H. Canseco-Sánchez et al., "Photovoltaic/thermal solar hybrid system with bifacial PV module and transparent plane collector," Solar Energy Materials and Solar Cells, vol. 91, no. 20, pp. 1966-1971, 2007.

[112] J. Ji, T. T. Chow, and W. He, "Dynamic performance of hybrid photovoltaic/thermal collector wall in Hong Kong," Building and Environment, vol. 38, no. 11, pp. 1327-1334, 2003.

[113] T. T. Chow, A. L. S. Chan, K. F. Fong, W. C. Lo, and C. L. Song, "Energy performance of a solar hybrid collector system in a multistory apartment building," Proceedings of the Institution of Mechanical Engineers A, vol. 219, no. 1, pp. 1-11, 2005.

[114] T. T. Chow, W. He, and J. Ji, "An experimental study of façade-integrated photovoltaic/water-heating system," Applied Thermal Engineering, vol. 27, no. 1, pp. 37-45, 2007.

[115] J. Ji, J. Han, T. T. Chow et al., "Effect of fluid flow and packing factor on energy performance of a wall-mounted hybrid photovoltaic/water-heating collector system," Energy and Buildings, vol. 38, no. 12, pp. 1380-1387, 2006.

[116] T. T. Chow, W. He, A. L. S. Chan, K. F. Fong, Z. Lin, and J. Ji, "Computer modeling and experimental validation of a building-integrated photovoltaic and water heating system," Applied Thermal Engineering, vol. 28, no. 11-12, pp. 13561364, 2008.

[117] T. T. Chow, A. L. S. Chan, K. F. Fong, Z. Lin, W. $\mathrm{He}$, and J. Ji, "Annual performance of building-integrated photovoltaic/water-heating system for warm climate application," Applied Energy, vol. 86, no. 5, pp. 689-696, 2009.

[118] T. T. Chow and J. Ji, "Environmental life-cycle analysis of hybrid solar photovoltaic/thermal systems for use in Hong Kong," International Journal of Photoenergy, vol. 2012, Article ID 101968, 9 pages, 2012.

[119] T. N. Anderson, M. Duke, G. L. Morrison, and J. K. Carson, "Performance of a building integrated photovoltaic/thermal (BIPVT) solar collector," Solar Energy, vol. 83, no. 4, pp. 445455, 2009.

[120] F. Ghani, M. Duke, and J. K. Carson, "Effect of flow distribution on the photovoltaic performance of a building integrated photovoltaic/thermal (BIPV/T) collector," Solar Energy, vol. 86, no. 5, pp. 1518-1530, 2012.

[121] U. Eicker and A. Dalibard, "Photovoltaic-thermal collectors for night radiative cooling of buildings," Solar Energy, vol. 85, no. 7, pp. 1322-1335, 2011

[122] T. Matuska, "Simulation study of building integrated solar liquid PV-T collectors," International Journal of Photoenergy, vol. 2012, Article ID 686393, 8 pages, 2012.

[123] C. D. Corbin and Z. J. Zhai, "Experimental and numerical investigation on thermal and electrical performance of a building integrated photovoltaic-thermal collector system," Energy and Buildings, vol. 42, no. 1, pp. 76-82, 2010.

[124] M. Bakker, H. A. Zondag, M. J. Elswijk, K. J. Strootman, and M. J. M. Jong, "Performance and costs of a roof-sized
PV/thermal array combined with a ground coupled heat pump," Solar Energy, vol. 78, no. 2, pp. 331-339, 2005.

[125] Y. Bai, T. T. Chow, C. Ménézo, and P. Dupeyrat, "Analysis of a hybrid PV/thermal solar-assisted heat pump system for sports center water heating application," International Journal of Photoenergy, vol. 2012, Article ID 265838, 13 pages, 2012.

[126] J. Ji, K. Liu, T. T. Chow, G. Pei, W. He, and H. He, "Performance analysis of a photovoltaic heat pump," Applied Energy, vol. 85, no. 8, pp. 680-693, 2008.

[127] J. Ji, G. Pei, T. T. Chow et al., "Experimental study of photovoltaic solar assisted heat pump system," Solar Energy, vol. 82 , no. 1 , pp. $43-52,2008$

[128] J. Ji, K. Liu, T. T. Chow, G. Pei, and H. He, "Thermal analysis of $\mathrm{PV} / \mathrm{T}$ evaporator of a solar-assisted heat pump," International Journal of Energy Research, vol. 31, no. 5, pp. 525-545, 2007.

[129] J. Ji, H. He, T. T. Chow, G. Pei, W. He, and K. Liu, "Distributed dynamic modeling and experimental study of PV evaporator in a PV/T solar-assisted heat pump," International Journal of Heat and Mass Transfer, vol. 52, no. 5-6, pp. 1365-1373, 2009.

[130] T. T. Chow, K. F. Fong, G. Pei, J. Ji, and M. He, "Potential use of photovoltaic-integrated solar heat pump system in Hong Kong," Applied Thermal Engineering, vol. 30, no. 8-9, pp. 1066-1072, 2010.

[131] G. Pei, J. Ji, T. T. Chow, H. He, K. Liu, and H. Yi, "Performance of the photovoltaic solar-assisted heat pump system with and without glass cover in winter: a comparative analysis," Proceedings of the Institution of Mechanical Engineers A, vol. 222, no. 2, pp. 179-187, 2008.

[132] G. Pei, H. Fu, H. Zhu, and J. Ji, "Performance study and parametric analysis of a novel heat pipe PV/T system," Energy, vol. 37, no. 1, pp. 384-395, 2012.

[133] G. Pei, H. Fu, J. Ji, T. T. Chow, and T. Zhang, "Annual analysis of heat pipe PV/T systems for domestic hot water and electricity production," Energy Conversion and Management, vol. 56, pp. 8-21, 2012.

[134] S. Y. Wu, Q. L. Zhang, L. Xiao, and F. H. Guo, "A heat pipe photovoltaic/thermal (PV/T) hybrid system and its performance evaluation," Energy Build, vol. 43, no. 12, pp. $3558-3567,2011$.

[135] F. Calise, M. D. d'Accadia, and L. Vanoli, "Design and dynamic simulation of a novel solar trigeneration system based on hybrid photovoltaic/thermal collectors (PVT)," Energy Conversion and Management, vol. 60, pp. 214-225, 2012.

[136] A. Segal, M. Epstein, and A. Yogev, "Hybrid concentrated photovoltaic and thermal power conversion at different spectral bands," Solar Energy, vol. 76, no. 5, pp. 591-601, 2004.

[137] A. Royne, C. J. Dey, and D. R. Mills, "Cooling of photovoltaic cells under concentrated illumination: a critical review," Solar Energy Materials and Solar Cells, vol. 86, no. 4, pp. 451-483, 2005.

[138] J. I. Rosell, X. Vallverdu, M. A. Lechon, and M. Ibanez, "Design and simulation of a low concentrating photovoltaic/thermal system," Energy Conversion and Management, vol. 46, no. 18-19, pp. 3034-3046, 2005.

[139] M. Li, G. L. Li, X. Ji, F. Yin, and L. Xu, "The performance analysis of the trough concentrating solar photovoltaic/thermal system," Energy Conversion and Management, vol. 52, no. 6, pp. 2378-2383, 2011. 
[140] X. Ji, M. Li, W. Lin, W. Wang, L. Wang, and X. Luo, "Modeling and characteristic parameters analysis of a trough concentrating photovoltaic/thermal system with GaAs and super cell arrays," International Journal of Photoenergy, vol. 2012, Article ID 782560, 10 pages, 2012.

[141] G. Li, G. Pei, S. Yuehong, X. Zhou, and J. Ji, "Preliminary study based on building-integrated compound parabolic concentrators (CPC) PV/thermal technology," Energy Procedia, vol. 14, pp. 343-350, 2012.

[142] L. Zhang, D. Jing, L. Zhao, J. Wei, and L. Guo, "Concentrating $\mathrm{PV} / \mathrm{T}$ hybrid system for simultaneous electricity and usable heat generation: a review," International Journal of Photoenergy, vol. 2012, Article ID 869753, 8 pages, 2012.

[143] J. S. Coventry, "Performance of a concentrating photovoltaic/thermal solar collector," Solar Energy, vol. 78, no. 2, pp. 211-222, 2005.

[144] A. Kribus, D. Kaftori, G. Mittelman, A. Hirshfeld, Y. Flitsanov, and A. Dayan, "A miniature concentrating photovoltaic and thermal system," Energy Conversion and Management, vol. 47, no. 20, pp. 3582-3590, 2006.

[145] J. Nilsson, H. Håkansson, and B. Karlsson, "Electrical and thermal characterization of a PV-CPC hybrid," Solar Energy, vol. 81, no. 7, pp. 917-928, 2007.

[146] Y. Vorobiev, J. González-Hernández, P. Vorobiev, and L. Bulat, "Thermal-photovoltaic solar hybrid system for efficient solar energy conversion," Solar Energy, vol. 80, no. 2, pp. 170-176, 2006 .

[147] Y. V. Vorobiev, J. González-Hernández, and A. Kribus, "Analysis of potential conversion efficiency of a solar hybrid system with high-temperature stage," Journal of Solar Energy Engineering, vol. 128, no. 2, pp. 258-260, 2006.

[148] S. Jiang, P. Hu, S. Mo, and Z. Chen, "Optical modeling for a two-stage parabolic trough concentrating photovoltaic/thermal system using spectral beam splitting technology," Solar Energy Materials and Solar Cells, vol. 94, no. 10, pp. 1686-1696, 2010.

[149] L. T. Kostic, T. M. Pavlovic, and Z. T. Pavlovic, "Influence of reflectance from flat aluminum concentrators on energy efficiency of PV/Thermal collector," Applied Energy, vol. 87, no. 2, pp. 410-416, 2010.

[150] Y. Xuan, X. Chen, and Y. Han, "Design and analysis of solar thermophotovoltaic systems," Renewable Energy, vol. 36, no. 1, pp. 374-387, 2011.

[151] G. Kosmadakis, D. Manolakos, and G. Papadakis, "Simulation and economic analysis of a CPV/thermal system coupled with an organic Rankine cycle for increased power generation," Solar Energy, vol. 85, no. 2, pp. 308-324, 2011.

[152] H. Huang, Y. Li, M. Wang et al., "Photovoltaic-thermal solar energy collectors based on optical tubes," Solar Energy, vol. 85, no. 3, pp. 450-454, 2011.

[153] L. T. Yan, F. L. Wu, L. Peng et al., "Photoanode of dyesensitized solar cells based on a $\mathrm{ZnO} / \mathrm{TiO}_{2}$ composite film," International Journal of Photoenergy, vol. 2012, Article ID 613969, 4 pages, 2012.

[154] S. Kumar and A. Tiwari, "An experimental study of hybrid photovoltaic thermal (PV/T)-active solar still," International Journal of Energy Research, vol. 32, no. 9, pp. 847-858, 2008.

[155] S. Kumar and G. N. Tiwari, "Life cycle cost analysis of single slope hybrid (PV/T) active solar still," Applied Energy, vol. 86, no. 10, pp. 1995-2004, 2009.

[156] S. Kumar and A. Tiwari, "Design, fabrication and performance of a hybrid photovoltaic/thermal (PV/T) active solar still," Energy Conversion and Management, vol. 51, no. 6, pp. 1219-1229, 2010.
[157] M. K. Gaur and G. N. Tiwari, "Optimization of number of collectors for integrated PV/T hybrid active solar still," Applied Energy, vol. 87, no. 5, pp. 1763-1772, 2010.

[158] G. N. Tiwari, S. Nayak, S. Dubey, S. C. Solanki, and R. D. Singh, "Performance analysis of a conventional PV/T mixed mode dryer under no load condition," International Journal of Energy Research, vol. 33, no. 10, pp. 919-930, 2009.

[159] G. Mittelman, A. Kribus, and A. Dayan, "Solar cooling with concentrating photovoltaic/thermal (CPVT) systems," Energy Conversion and Management, vol. 48, no. 9, pp. 24812490, 2007.

[160] G. Mittelman, A. Kribus, O. Mouchtar, and A. Dayan, "Water desalination with concentrating photovoltaic/thermal (CPVT) systems," Solar Energy, vol. 83, no. 8, pp. 1322-1334, 2009.

[161] H. Zondag, J. Bystrom, and J. Hansen, "PV-thermal collectors going commercial," IEA SHC Task 35 paper, 2008.

[162] J. Hansen, H. Sørensen, J. Byström, M. Collins, and B. Karlsson, "Market, modelling, testing and demonstration in the framewrk of IEA SHC Task 35 on PV/thermal solar systems," in Proceedings of the 22nd European Photovoltaic Solar Energy Conference and Exhibition, DE2-5, Milan, Italy, September 2007.

[163] C. L. Shen and J. C. Su, "Grid-connection half-bridge PV inverter system for power flow controlling and active power filtering," International Journal of Photoenergy, vol. 2012, Article ID 760791, 8 pages, 2012.

[164] D. Amorndechaphon, S. Premrudeepreechacharn, K. Higuchi, and X. Roboam, "Modified grid-connected CSI for hybrid PV/wind power generation system," International Journal of Photoenergy, vol. 2012, Article ID 381016, 12 pages, 2012.

[165] M. J. Elswijk, H. A. Zondag, and W. G. J. van Helden, "Indoor test facility PVT-panels—a feasibility study," Energy Research Centre of the Netherlands, ECN-I-02-005, 2002. 